\title{
TASK AND MANAGEMENT SUPERVISION \\ OF GUIDANCE AND COUNSELING
}

\author{
Tri Anjar
}

Universitas Muhammadiyah Metro

\begin{abstract}
Improving the quality of guidance and counseling services in the educational unit requires the support of other parties. Process guidance and supervision right, and carried out by competent and professional personnel are needed to support the quality of counseling services performed by teachers BK. BK control activities include activities supervisor, educator, and motivator. The pattern of structured supervision, honest, and based on the analysis of the problems the ministry guidance and counseling in schools, will be able to give a good contribution to the improvement, evaluation, and improvement of guidance and counseling services, as well as the professionalism of teachers BK as a service provider.
\end{abstract}

Keyword: guidance, counseling, supervision, management

PENDAHULUAN

Peningkatan kualitas

pelayanan bimbingan dan konseling pada dasarnya akan tercapai dengan peningkatan kualitas dan profesionalitas guru BK. Peningkatan kualitas guru BK dapat diperoleh melalui pendidikan lanjut (S2 BK), mengikuti pendidikan Profesi Guru BK, aktif dalam kegiatan pelatihan dan seminarseminar. Selain upaya peningkatan kualitas yang berasal dari diri guru BK itu sendiri, dukungan dan pembinaan dari pihak lain sangat dibutuhkan dalam peningkatan kualitas guru BK, salah satunya yaitu melalui kegiatan pengawasan.

Mengacu pada Peraturan Pemerintah Nomor 74 tahun 2008 tentang Guru Pasal 54 ayat (8) dan (9) pengawas terdiri dari: pengawas satuan pendidikan, (2) pengawas mata pelajaran, atau pengawas kelompok mata pelajaran, dan pengawasan terhadap kegiatan Bimbingan dan konseling secara langsung masuk ke dalamnya. Layanan bimbingan dan konseling merupakan kegiatan yang 
terencana berdasarkan pengukuran kebutuhan (need asessment) yang diwujudkan dalam bentuk program bimbingan dan konseling Program menjadi landasan yang jelas untuk mengukur layanan profesional yang diberikan oleh guru BK/Konselor di sekolah. Sasaran pengawasan bidang bimbingan dan konseling meliputi seluruh kegiatan bimbingan dan konseling di sekolah, baik dari jenjang pendidikan dasar, menengah, dan pendidikan tinggi.

Peraturan Menteri

Pendidikan Nasional Nomor 12 Tahun 2007 tentang Standar Pengawas Sekolah/Madrasah menegaskan bahwa seorang pengawas harus memiliki 6 (enam) kompetensi minimal, yaitu kompetensi kepribadian, supervisi manajerial, supervisi akademik, evaluasi pendidikan, penelitian dan pengembangan serta kompetensi sosial.

Kondisi di lapangan saat ini tentu saja masih banyak pengawas sekolah/madrasah yang belum menguasai keenam dimensi kompetensi tersebut dengan baik. Persoalan yang terjadi secara global (dalam hal pengawasan) tersebut di atas juga merambah ke dalam pengawasan bidang Bimbingan dan Konseling. Survei yang dilakukan oleh Direktorat Tenaga Kependidikan pada Tahun 2008 terhadap para pengawas di suatu kabupaten menunjukkan bahwa para pengawas memiliki kelemahan dalam kompetensi supervisi akademik, evaluasi pendidikan, dan penelitian dan pengembangan. Sosialisasi dan pelatihan yang selama ini biasa dilaksanakan dipandang kurang memadai untuk menjangkau keseluruhan pengawas dalam waktu yang relatif singkat. Selain itu, karena terbatasnya waktu maka intensitas dan kedalaman penguasaan materi kurang dapat dicapai dengan kedua strategi ini.

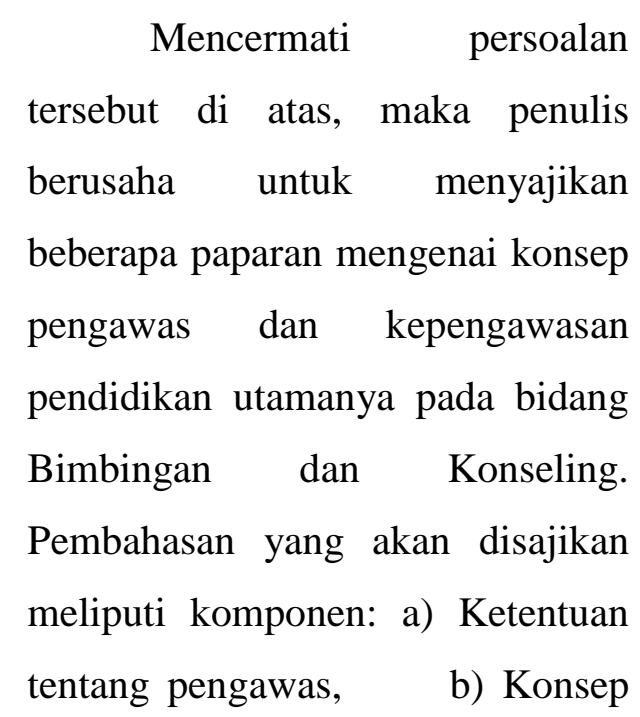


pengawas Bimbingan dan

Konseling, c) Tugas dan tanggung jawab pengawas Bimbingan dan Konseling, d) Tujuan pengawas Bimbingan dan Konseling, dan e) Aplikasi Ketentuan Tentang PengawasBimbingan dan Konseling di Sekolah.

Tujuan utama dari pembahasan adalah memberikan pemahaman dan konsep yang benar tentang:

a. Ketentuan tentang pengawas

b. Konsep pengawas Bimbingan dan Konseling

c. Tugas dan tanggung jawab pengawas Bimbingan dan Konseling d. Tujuan pengawas Bimbingan dan Konseling

e. Aplikasi Ketentuan Tentang

PengawasBimbingan dan Konseling di Sekolah

\section{PEMBAHASAN}

1. Ketentuan Tentang Pengawas

Pengawas dan pengawasan merupakan kegiatan yang bertujuan untuk meningkatkan profesionalitas yang diawasi. Oleh karena itu, pelaksanaan pengawasan oleh pengawas harus memperhatikan dasar hukum yang memayunginya. Berikut ketentuan yang menjadi dasar kegiatan pengawasan di sekolah:

a) Pembukaan UUD 1945, yang bertujuan secara menyeluruh dan mendasar mengupayakan pendidikan yang diselenggarakan oleh bangsa dan Negara Indonesia adalah untuk mencerdaskan

kehidupan bangsa;

b) Undang-undang No. 20 Tahun 2003 tentang Sistem Pendidikan Nasional.

c) Undang-Undang Republik Indonesia Nomor 14 Tahun 2005 tentang Guru dan Dosen

d) Peraturan Pemerintah Republik Indonesia Nomor 19 Tahun 2005 tentang Standar Nasional Pendidikan, 
e) Peraturan Pemerintah

Pengawas Satuan

Republik Indonesia

Pendidikan.

Nomor 22 Tahun 2006

k) Ketentuan-ketentuan

tentang Standar Isi

f) Peraturan Pemerintah lain yang menyangkut pengawas

Republik Indonesia sekolah/madrasah.

Nomor 48 Tahun 2008

tentang Pendanaan

Pendidikan,

g) Peraturan Pemerintah

Republik Indonesia

Nomor 74 Tahun 2008

tentang Guru,

h) Peraturan Menteri

Pendidikan Nasional

Nomor 19 Tahun 2005

Tentang Penetapan

Angka Kredit Jabatan

Fungsional Pengawas

Sekolah

i) Peraturan Menteri

Pendidikan Nasional

Nomor 12 Tahun 2007

tentang Standar

Pengawas

Sekolah/Madrasah

j) Peraturan Menteri

Pendidikan Nasional

Nomor 39 Tahun 2009

Tentang Pemenuhan

Beban Kerja Guru dan

2. Konsep Pengawas

Kegiatan pengawasan adalah kegiatan Pengawas Satuan Pendidikan dalam melaksanakan penyusunan program pengawasan satuan pendidikan, pelaksanaan pembinaan akademik dan administrasi, pemantauan delapan standar nasional pendidikan, penilaian administrasi dan akademik, dan pelaporan pelaksanaan program pengawasan (Depdiknas, 2009: 70).

Permendiknas Nomor 12 tahun 2007 tentang Standar Pengawas Sekolah/Madrasah, menyatakan bahwa jenis pengawas terdiri dari 1). Pengawas Taman KanakKanak/Raudatul Athfal (TK/RA) dan Sekolah Dasar/Madrasah Ibtidaiyah (SD/MI), 2). Pengawas Sekolah Menengah 
Pertama/Madrasah Tsanawiyah

(SMP/MTs) dan Pengawas

Sekolah

Menengah

Atas/Madrasah

Aliyah

(SMA/MA) dalam Rumpun

Mata Pelajaran yang Relevan

(MIPA dan TIK, IPS, Bahasa,

Olahraga Kesehatan, atau Seni

Budaya), 3). Pengawas

Sekolah

Menengah

Kejuruan/Madrasah Aliyah

Kejuruan (SMK/MAK) dalam

Rumpun Mata Pelajaran yang

Relevan (MIPA dan TIK, IPS,

Bahasa, Olahraga Kesehatan,

Seni Budaya, Teknik dan

Industri, Pertanian dan

Kehutanan, Bisnis dan

Manajemen, Pariwisata,

Kesejahteraan Masyarakat,

atau Seni dan Kerajinan).

Sedangkan dalam

bidang bimbingan dan

konseling, pengawas kegiatan

bimbingan dan konseling

diartikan sebagai kegiatan

pengawas sekolah yang

menyelenggarakan

kepengawasan dengan tugas

pokok mengadakan penilaian

dan pembinaan melalui arahan,

bimbingan, contoh dan saran kepada guru pembimbing/guru BK/konselor (Prayitno, 2001: 24).

\section{Tugas dan Tanggung Jawab Pengawas Bimbingan dan \\ Konseling}

a. Tugas pengawas bidang bimbingan dan konseling

Pengawas dapat

melakukan pengawasan dan pembinaan apakah program bimbingan dan konseling yang disusun dilaksanakan sesuai dengan rancangan program? Apakah terdapat dokumentasi sebagai indikator pencatatan pelaksanaan program? Pengawas dapat berdiskusi dengan konselor mengenai program-program mana yang sudah dilaksanakan? Apa hambatan yangditemui saat melaksanakan program? Apakah dapat diidentifikasikeberhasilan yang dicapai program? Apakah dapat diperoleh informasidampak langsung maupun tidak langsung 
pelaksanaan program

terhadapsiswa, pendidik

maupun institusi pendidikan?

Pertanyaan-pertanyaan

tersebut merupakan sedikit dari

upaya pengawas untuk

melakukan pengawasan

terhadap guru BK/guru

pembimbing/konselor di

sekolah/madrasah, yang

tentunya jawabannya adalah

bukan sekedar kata, melainkan

tindakan nyata baik yang

dilakukan guru BK/guru

pembimbing/konselor ataupun

pengawas sebagai tenaga

fungsional dalam upaya

penjaminan mutu pendidikan.

Tugas pengawas bidang bimbingan dan konseling (Depdiknas, 2009 yang merujuk pada PP No. 74 tahun 2008) dalam melakukan pembimbingan dan pelatihan profesional guru dan pengawasannya, yang di dalamnya telah ter-include konsep SEM pengawas dapat dirincikan sebagai berikut:
1) Penyusunan program pengawasan bimbingan dan konseling;

2) Melaksanakan pembinaan, pemantauan dan penilaian kegiatan bimbingan dan konseling;

3) Menyusun laporan pelaksanaan program pengawasan kegiatan bimbingan dan konseling;

4) Melakukan analisis pelaksanaan program pengawasan kegiatan bimbingan dan konseling;

5) Melaksanakan pembimbingan dan pelatihan profesionalitas guru BK melalui kegiatan berskala regional hingga Internasional (seminar, lokakarya, workshop, MGBK, talk show, dll).

6) Mengawasi, memantau, mengolah, dan melaporkan hasil pelaksanaan 8 (delapan) standar nasional pendidikan pada satuan pendidikan;

7) Membimbing satuan pendidikan untuk meningkatkan atau 
mempertahankan

kelayakan

program

dan/atau

satuan

pendidikan.

b. Tanggung jawab pengawas bidang bimbingan dan konseling

Kegiatan bagi pengawas bimbingan dan konseling untuk melaksanakan tugas pokok dan tanggung jawabnya diatur sebagai berikut:

1) Ekuivalensi kegiatan kerja pengawas bimbingan dan konseling terhadap 24 (dua puluh empat) jam tatap muka dalam 1 (satu) minggu menggunakan pendekatan jumlah guru yang dibina di satu atau beberapa sekolah pada jenjang pendidikan yang sama atau jenjang pendidikan yang berbeda.

2) Jumlah guru yang harus dibina untuk pengawas bimbingan dan konseling paling sedikit 40 (empat puluh) dan paling banyak 60 guru BK (Depdiknas, 2009: 39).

\section{Tujuan Pengawas Bimbingan dan Konseling}

Adapun tujuan dari pengawas dan/atau pengawasan bidang bimbingan dan konseling antara lain adalah untuk:

a. Meningkatkan kemampuan guru BK dalam memanfaatkan lingkungan belajar

b. Meningkatkan kemampuan guru BK dalam menyusun dan melaksanakan program BK di sekolah

c. Menilai kemampuan guru BK dalam merencanakan pembelajaran melalui pelayanan $\mathrm{BK}$

d. Menilai kemampuan guru BK dalam melaksanakan proses pembelajaran melalui pelayanan $\mathrm{BK}$

e. Menilai kemampuan guru BK dalam menggunakan media dan sumber belajar

f. Menilai kemampuan guru BK dalam melaksanakan program bimbingan konseling di sekolah

g. Menilai kemampuan guru BK dalam meningkatkan 
hasil belajar siswa melalui layanan BK

h. Menilai kemampuan guru BK dalam melaksanakan penelitian tindakan kelas

i. Menilai kemampuan guru BK dalam melaksanakan pembaharuan pembelajaran

j. Membina guru BK dalam mempertinggi kompetensi profesionalnya

k. Membina disiplin guru BK dalam melaksanakan tugasnya sebagai agen pembelajaran

1. Membina guru BK dalam menggunakan teknologi informasi dan komunikasi untuk pembelajaran

m. Membina guru BK dalam mengembangkan karir profesi dan kepangkatannya

Muara dari keseluruhan item tersebut di atas adalah mengarah kepada penjaminan mutu pembelajaran dan/atau pendidikan. Penjaminan mutu (quality assurance) merupakan teknik untuk menentukan bahwa proses pendidikan telah berlangsung sebagaimana seharusnya. Dengan teknik ini akan dapat dideteksi adanya penyimpangan yang terjadi pada proses. Teknik ini menekankan pada monitoring yang berkesinambungan, dan melembaga, menjadi subsistem sekolah.

\section{Aplikasi Ketentuan Tentang PengawasBimbingan dan Konseling di Sekolah}

Pengawas melakukan pembinaan dan pengawasan dengan melakukandiskusi terfokus berkenaan dengan ketersediaan personil konselor sesuaidengan kebutuhan (berdasarkan jumlah siswa) serta upaya-upaya untukmemenuhi ketersediaan konselor, optimalisasi peran dan fungsi personilsekolah dalam layanan bimbingan dan konseling, serta mekanisme layanan sesuai dengan peran dan fungsinya. Aplikasi Ketentuan Tentang Pengawas Bimbingan dan Konseling di Sekolah lebih lanjut diuraikan sebagai berikut (Depdiknas, 2009:74): 
a. Penyusunan Program

Pengawasan Bimbingan dan

Konseling

1) Setiap pengawas baik secara berkelompok maupun secara perorangan wajib menyusun rencana program pengawasan. Program pengawasan terdiri atas (1) program pengawasan tahunan, (2) program pengawasan semester, dan (3) rencana kepengawasan akademik (RKA).

2) Program pengawasan tahunan pengawas disusun oleh kelompok pengawas di kabupaten/kota melalui diskusi terprogram. Kegiatan penyusunan program tahunan ini diperkirakan berlangsung selama 1 (satu) minggu.

3) Program pengawasan semester adalah perencanaan teknis operasional kegiatan yang dilakukan oleh setiap pengawas pada setiap sekolah tempat guru binaannya berada. Program tersebut disusun sebagai penjabaran atas program pengawasan tahunan di tingkat kabupaten/kota. Kegiatan penyusunan program semester oleh setiap pengawas ini diperkirakan berlangsung selama 1 (satu) minggu.

4) Rencana Kepengawasan Bimbingan dan Konseling (RKBK) merupakan penjabaran dari program semester yang lebih rinci dan sistematis sesuai dengan aspek/masalah prioritas yang harus segera dilakukan kegiatan supervisi. Penyusunan RKBK ini diperkirakan berlangsung 1 (satu) minggu.

5) Program tahunan, program semester, dan RKBK sekurang-kurangnya memuat aspek/masalah, tujuan, indikator keberhasilan, strategi/metode kerja (teknik supervisi), skenario kegiatan, sumberdaya yang diperlukan, penilaian dan instrument pengawasan. 


$\begin{array}{rrrr} & & \text { memiliki } & \text { batasan } \\ \text { kerja penyusunan } & \text { program } & \text { waktupencapaian atau } \\ & \text { pengawas } & \text { hendaknya } & \text { pelaksanaan yang jelas. }\end{array}$
memperhatikan kriteria yang disingkat dengan "SMART" (Specific, Measurable,

b. Melaksanakan Pembinaan, Achievable, Realistic and Time Bound).

1) Specific, artinya program yang disusun memiliki fokus yang jelas dan mencakup bidang tertentu secara khusus.

Pemantauan dan Penilaian

1) Kegiatan supervisi bimbingan dan konseling meliputi pembinaan dan pemantauan pelaksanaan bimbingan dan konseling di sekolah merupakan kegiatan dimana terjadi interaksi

2) Measureable, artinya program-program dan kegiatan-kegiatan yang dipilih dapat diukur pencapaiannya. langsung antara pengawas dengan guru binaanya.

3) Achieveable, artinya program-program yang dirancang terjangkau untuk dicapai, baik dari segi waktu, biaya maupun kondisi yang ada.

4) Realistics, artinya programprogram benar-benar didasarkan pada data atau kondisi dan kebutuhan riil sekolah-sekolah binaan serta tidak mengada-ada.

c. Menyusun Laporan Pelaksanaan Program

5) Time Bound, artiya Pengawasan program yang dirancang 
1) Setiap pengawas membuat laporan dalam bentuk laporan per sekolah dari seluruh sekolah binaan. Laporan ini lebih ditekankan kepada pencapaian tujuan dari setiap butir kegiatan pengawasan sekolah yang telah dilaksanakan pada setiap sekolah binaan,

2) Penyusunan laporan oleh pengawas merupakan upaya untuk mengkomunikasikan hasil kegiatan atau keterlaksanaan program yang telah direncanakan,

3) Menyusun laporan pelaksanaan program pengawasan dilakukan oleh setiap pengawas sekolah dengan segera setelah melaksanakan pembinaan, pemantauan atau penilaian.

d. Melaksanakan pembimbingan dan pelatihan profesionalitas guru BK.

1) Kegiatan pembimbingan dan pelatihan profesionalitas guru BK dilaksanakan paling sedikit
3 (tiga) kali dalam satu semester secara berkelompok di Musyawarah Guru Pembimbing (MGP/MGBK).

2) Kegiatan dilaksanakan terjadwal baik waktu maupun jumlah jam yang diperlukan untuk setiap kegiatan sesuai dengan tema atau jenis keterampilan dan kompetensi yang akan ditingkatkan.

3) Dalam pelatihan diperkenalkan kepada guru cara-cara baru yang lebih sesuai dalam melaksanakan suatu proses pembimbingan. Kegiatan pembimbingan dan pelatihan profesionalitas guru BK ini dapat dilakukan melalui workshop, seminar, observasi, individual dan group conference.

Secara umum, program pengawasan sekolah sekurangkurangnya memuat komponen pokok sebagai berikut:

a. Aspek/masalah, berupa identifikasi hasil 
pengawasan sebelumnya

sebagai prioritas dalam

rencana pengawasan

(pembinaan, pemantauan,

penilaian)

b. Tujuan pengawasan yang hendak dicapai.

c. Indikator keberhasilan, berupa target yang ingin dicapai

d. Strategi/metode kerja/teknik supervisi, seperti monitoring dan evaluasi, refleksi dan Focused Group Discussion, workshop, kunjungan kelas, observasi kelas, pertemuan individual, kunjungan antar kelas, supervisi kelompok, dll)

e. Skenario kegiatan, berupa langkah atau tahapan supervisi yang sistematis dan logis yang disesuaikan dengan jadwal dan waktu.

f. Sumber daya yang diperlukan, dapat berupa bahan, fasilitas, sumber daya manusia.

g. Penilaian dan instrumen, jenis dan bentuk disesuaikan dengan aspek/masalah yang akan diselesaikan. h. Rencana tindak lanjut, dapat berupa pemantapan, perbaikan berkelan-jutan disesuaikan dengan metode pengawasan.

\section{KESIMPULAN}

Kegiatan pengawasan bimbingan dan konseling memiliki peran yang sangat besar dalam menunjang kualitas pelayanan bimbingan dan konseling di sekolah. Pengawasan bimbingan dan konseling akan menjadi kegiatan yang profesional dan bersifat rekonstruktif jika dilakukan secara benar, berdasarkan prinsip keahlian, mengikuti ketentuan dan manajemen pengawasan yang tepat.

Proses pengawasan bimbingan dan konseling memerlukan personel yang memiliki kompetensi dibidang pengawasan, meliputi: Kepribadian, Sosial, Supervisi Manajerial, Supervisi Akademik, Evaluasi Pendidikan, Penelitian dan Pengembangan. Dengan demikian, tidak semua orang dapat menjadi pengawas 
BK dan melakukan proses pengawasan BK. Syarat minimal agar proses pengawasan berjalan dengan efektif adalah terpenuhinya keenam kompetensi tersebut

Dukungan kompetensi dan integritas pengawas sekolah, pada akhirnya akan membawa perbaikan bagi pelayanan konseling. Kegiatan pengawasan memiliki manfaat perbaikan kualitas pelayanan, organisasi BK di sekolah, peningkatan kualitas dan profesionalitas guru BK, serta menjadi mampu membangun motivasi bagi guru BK untuk lebih maju dan profesional.

\section{DAFTAR PUSTAKA}

Depdiknas. 2009. Pedoman Pelaksanaan Tugas Guru dan Pengawas. Dirjen PMPTK: Jakarta.

Depdiknas. 2009. Bahan Belajar Mandiri Kelompok Kerja Pengawas Sekolah Dimensi Kompetensi Supervisi Manajerial. Dirjen PMPTK: Jakarta.

Peraturan Pemerintah Republik Indonesia Nomor 74 Tahun 2008 tentang Guru.

Peraturan Menteri Pendidikan Nasional Nomor 19 Tahun 2005 Tentang Penetapan Angka Kredit Jabatan Fungsional Pengawas Sekolah.

Peraturan Menteri Pendidikan Nasional Nomor 12 Tahun 2007 tentang Standar Pengawas Sekolah/Madrasah.

Peraturan Menteri Pendidikan Nasional Nomor 39 Tahun 2009 Tentang Pemenuhan Beban Kerja Guru dan Pengawas Satuan Pendidikan.

Prayitno. 2001. Panduan Kegiatan Pengawasan Bimbingan dan Konseling di sekolah. Jakarta: PT. Rineka Cipta.

Sahertian, Piet. 1981. Prinsip dan Teknik Supervisi Pendidikan. Usaha Nasional: Surabaya. 